\title{
Special issue: Critical Latinx indigeneities
}

\author{
Maylei Blackwell ${ }^{1}$ - Floridalma Boj Lopez ${ }^{2}$. \\ Luis Urrieta $\mathbf{J r}^{3}$
}

(C) Macmillan Publishers Ltd 2017

\section{Introduction}

\section{Critical Latinx indigeneities}

This special issue emerges out of a need to examine how Indigenous migrants from Latin America are transforming notions of Latinidad and indigeneity in the US. The articles gathered in this issue collectively consider how the growing presence of an Indigenous diaspora from Latin America is shifting and raising questions about transnational meanings of race, place, and indigeneity. We have come together to call attention to the ways Indigenous Latinx communities mobilize particular forms of activism and scholarship that require new conceptual framing. As a step in that direction, we propose Critical Latinx Indigeneities as a framework produced through our collective conversations with the contributors to the special issue as well as many other colleagues. Together, we are conceptualizing Critical Latinx Indigeneities as an interdisciplinary analytic that reflects how indigeneity is defined and constructed across multiple countries and at times, across overlapping colonialities. This includes thinking through the colonial legacies at play across

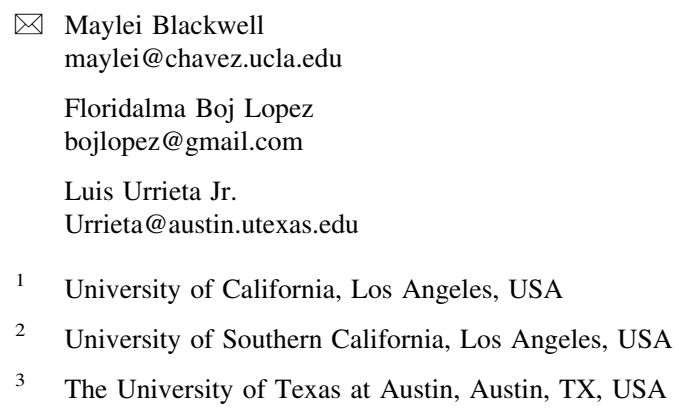


the transregions created by Indigenous migration (Jonas and Rodríguez 2015). Too many studies of migration collude with the myth that the United States is a nation of immigrants which replicates, even if unwittingly, the settler colonial logic of erasure and elimination of Indigenous peoples. ${ }^{1}$ These studies reproduce the discourse of terra nullius whereby occupation and settlement are justified through the myth that the land is vacant of Indigenous people and therefore, a blank slate on which immigrants remake their lives and transnational communities. This discourse (re)produces a logic of elimination that becomes part of a settler commonsense whereby Native Americans are either nonexistent or disappearing. ${ }^{2}$ We challenge this view by calling on scholars in Latina/o studies to follow the lead of Asian settler colonialism scholars in Hawai'i (Fujikane and Okamura 2008) by recognizing that $\mathrm{im} /$ migrants arrive on the homelands and nations of Indigenous peoples and that this awareness brings with it responsibilities and the possibility of new relationships of tension and solidarity (Aikau 2010; Boj Lopez 2015). Further, we build on the work of Candace Fujikane and Jonathan Okamura (2008) and the Asian settler colonialism scholarship that argues against another extension of the logic of elimination that posits that when Indigenous people migrate, they cease to be Indigenous. Thus, Critical Latinx Indigeneities, as a lens of analysis, understands the co-constitutive relationship of multiple contexts of power and multiple colonialities (Blackwell, this issue) and begins the difficult conversation about the role of Indigenous people who are settlers in the homelands and nations of other Indigenous people. For example, Indigenous Latinx migrants flee political and economic violence and colonial structures in their countries of origin, despite the fact that many countries in Latin America contain large populations of Indigenous peoples, and some even have majority Indigenous populations. These historic and current structural issues in Latin America and the Caribbean are impacted by neoliberal forces and imperialist wars of intervention that engineer the dislocation and dispossession of migrants, not only as laborers, but also as Indigenous peoples. These policies create migrant populations that are forced to encounter new and old structures that seek to manage and erase indigeneity. Often the racism migrants experience is the entrenched anti-Indian hatred enacted by mestizos and Ladinos as they migrate from Southern Mexico and Central America through Mexico, as well as once they arrive in the United States. We therefore establish that similar to Asian settlers in Hawai'i, Indigenous migrants from Latin America are also settlers on other Indigenous peoples' lands, but like Fujikane and Okamura (2008), we also simultaneously deny that all Indigenous migrants have the political capacity to colonize Northern Native nations.

\footnotetext{
${ }^{1}$ Settler colonialism has emerged as a powerful critique within Native American studies in part because it is defined as "a structure not an event" (Wolfe 1999, p. 2). Native American studies scholars have expanded the concept of settler colonialism in the development of structural critiques that are representative of what is now termed Critical Indigenous studies (Barker 2011; Byrd 2011, Coulthard 2014; Grande 2015; Simpson 2014).

${ }^{2}$ Although the logic of elimination was initially coined by Wolfe (2006), scholars like Mark Rifkin (2014) and Jean O'Brien (2010) have done work to explicitly chart its discursive power in becoming widespread and functioning in, "the ways the legal and political structures that enable nonnative access to Indigenous territories come to be lived as given, as simply the unmarked, generic conditions of possibility for occupancy, association, history, and personhood" (Rifkin 2014, p. xvi).
} 
Latin American structures of coloniality and racial domination interface with US racial and economic hierarchies and settler colonial structures. When two systems of indigeneity and racial/class hierarchy hybridize in the process of migration, they create what Blackwell has described as hybrid hegemonies (2010). For instance, this hybridization happens at a structural level as many Mayan migrants fleeing displacement, intergenerational poverty and violence in places like Guatemala, then become the largest population of unaccompanied migrant children and families apprehended by Border Patrol ${ }^{3}$ (Hernandez 2015), exposing them to multiple forms of violence that remain entrenched in their exclusion as Indigenous people. ${ }^{4}$ The continual experience of dispossession, not solely across time but also across space and borders has pushed us to develop Critical Latinx Indigeneities as simultaneously both a local and a hemispheric approach. While the policies that shape the exclusion of Indigenous migrants shifts across national borders, they are nonetheless predicated on denying Indigenous peoples the right to live in their communities of origin or to create new communities.

Racism and prejudice against Indigenous peoples by mestizos and Ladinos is exemplified by the recent anti-hate speech campaign aimed at Latino youth who had been bullying their Oaxacan peers in the city of Oxnard as well as in other parts of California (Barillas-Chon 2010). The intersection of structural factors that create hybrid hegemonies is illustrated by the fact that Indigenous farm workers are estimated to be $30 \%$ of the current agricultural sector of California and yet these Indigenous migrants from Oaxaca, often monolingual Mixtec and Triqui speakers, usually earn less than their mestizo counterparts for the same grueling work. Examining the transnational movement of anti-Indian hatred allows us to delve into a deeper exploration of how the Latino category erases Indigenous difference even as it enacts violence against Indigenous migrants as was the case in the shooting death of Maya K'iche' day laborer Manuel Jamines Xum in 2010. Xum was shot by two Latino officers from the Los Angeles Police Department (LAPD), and it remains unclear whether he understood the commands given by the officers in English and Spanish. These disjunctures and contradictions within the "Latina/o" population remind us that Latina/o populations are multiracial.

A frame of Critical Latinx Indigeneities allows us to forge a hemispheric analysis capable of examining more than one racial structure and the multiple colonial forces (re)shaping indigeneity (Castellanos et al. 2012). This analytic frame further examines the internal racial dynamics that are informed as much by Mexico and Guatemala, for example, as they are by the United States. Critical Latinx Indigeneities forces us to consider both the overlap and difference that Mayas, Zapotecs, Mixtecs, Garífuna, and P'urhépecha, among others, have in relation to Northern Native communities and does not naturalize displacement and migration by simply claiming that the entire hemisphere is Indigenous land or by pointing to precolonial routes and relations that predate nation-state borders. This analysis requires the ability to scale down to local shared understandings of indigeneity as well as to scale up to think about the logics of elimination and control that operate

\footnotetext{
${ }^{3}$ Southwest Border Unaccompanied Alien Children Statistics FY (2016).

${ }^{4}$ See Reynolds (2013), Menjívar and Abrego (2012).
} 
through particular structures across the hemisphere. This means grappling with not only the politics and policies of genocide and erasure in sending countries, but also the hybridization of these with US racial hierarchies that are premised on Native dispossession.

As an interdisciplinary conversation, this special issue is a timely intervention in what the current political climate boasts as the Latinoization of the US, due to the demographic growth of Latinxs. By simply noting the increase in population size, such research and media coverage rarely recognizes the actual increase in Latinx diversity, especially that caused by Indigenous and Afro-Latinx diasporas. In an effort to problematize and engage how intra-Latinx racism positions Indigenous migrants from Latin America as the invisible or inferior Other within the larger Latinx population, especially in issues of labor, health care, carceral policing structures, and within institutions such as schooling, we emphasize the lived experiences and struggles of Indigenous migrants and of second-and futuregenerations, for social justice.

\section{An intervention at the intersections of three interdisciplines: Latinx studies, critical indigenous studies, and Latin American studies}

Critical Latinx Indigeneities exists at the intersections of the three interdisciplinary fields of Native American and Indigenous studies, Latinx studies, and Latin American studies. These fields are often conceptualized as separate and distinct, but the Latin American and Caribbean Indigenous diaspora pushes the boundaries of all three fields. We draw from the political and intellectual traditions and knowledge projects born of the struggle for Indigenous studies and ethnic studies in the US and widen the frames of these fields hemispherically. Drawing from the "critical turn" in critical ethnic studies and critical Indigenous studies (Simpson and Smith 2014; Moreton-Robinson 2016; Critical Ethnic Studies Editorial Collective 2016), we use the term "critical" and capitalize Indigenous (including in its use as an adjective) to note our alignment with these intellectual and political projects. In highlighting the critical, we signal that our analytic is part of a reflective conversation used to break open the entrapment of reductive binaries of dominance/dependence or oppression/ agency. In exploring the political, social, and cultural contexts of the growing presence and realities of the Latin American and Caribbean Indigenous diaspora, we seek to tease through the merits and faults of existing frameworks.

We use the term "Latinx" to embrace the challenge to gender binaries posed by LGBT, genderqueer, and nonnormative gender activists and intellectuals. Latinx reflects the shifting terrain of identification and the ongoing commitment to building unity through embracing the diversity of Latinidad by not erasing difference and specificity. Further, the term Latinx is an important tool to signal the colonial nature of the imposition of gender binaries and opens up the possibility for recognizing the diversity of Indigenous sex gender systems in the Americas, many of which included more than two genders. Finally, we call for the acknowledgement and consideration of the complex, multilayered, and multi-vocal ways of being Indigenous, especially those being recognized, developed, deployed, and negotiated across national (colonial and Indigenous) borders through overlapping colonialities 
and settler states and within migrant transregions, which often cross multiple ethnoracial structures. This includes scaling up to examine how states manage or erase Indigenous lives, while also rooting the analysis in local specific linguistic and geographic communities.

Critical Latinx Indigeneities builds on a rich literature on Indigenous migration (Kearney 2000; Fox and Rivera-Salgado 2004; Velasco 2005; Stephen 2007). We would also like to acknowledge those who have struggled to create spaces for exchange and metorship for scholars of Latinx indigeneities in institutions of higher learning and within the professional associations, notably Inés Hernández Ávila and Inés Talamontes. While we call attention to the multifaceted nature of migration as a multiracial, multiethnic process (Fox 2006), a Critical Latinx Indigeneities lens pushes us to complicate theoretical frames such as illegality and to insist that, as powerful as this conceptual tool is, it must be understood from an intersectional approach that includes indigeneity. This more nuanced approach calls attention to how categories like illegality are compounded and multiplied by simultaneous intersecting oppressions like indigeneity (Herrera 2016). As such, Critical Latinx Indigeneities is a lens for understanding the ways indigeneity, gender, sexuality, ethnicity, race, class and other intersecting oppressions are produced over multiple contexts.

While the global political economy has resulted in the mass migration of Indigenous people from Latin America, we call attention to the ways transnational Indigenous communities negotiate the ongoing movement and flow of people, ideas and strategies in order to maintain identities that center their Indigenous ways of knowing and being in the world. The ways Indigenous migrants navigate these nation-state borders and internal borders of power create what Lynn Stephen calls transborder communities and transborder lives (2007). We recognize that Indigenous communities organize around language, epistemology, transnationalism and youth cultural practice to ensure the survival of their collectives as distinct Indigenous peoples who confront displacement and migration with creative forms of cultural cohesion (Urrieta 2016).

We also recognize that transnationalism and transnationality in Northern Native studies has been associated with an investment in the colonizing political structures of the settler state (Bauerkemper and Stark 2012). Rarely have US and Canadian Native scholars taken up a transnationalism framework, in part because of the intimate investment and commitment to the political project of Indigenous nationhood, and also because of the logic of capitalism that transnationalism advances (Warrior 2009). While we acknowledge these critiques as legitimate concerns, we also appreciate the advancement and possibilities of an emerging Indigenous transnationalism framework (Huang et al. 2012; Bauerkemper and Stark 2012), which seeks to restructure transnationalism in terms of Indigenous peoples' experiences and realities and centers Indigenous-to-Indigenous relationships, including shared alliances, social structures, and practices that take place within the boundaries of Indigenous nationhood, including through migration, and that do not re(center) the settler state. Therefore, while we acknowledge that Indigenous peoples from Latin America can enact settler logics, there is also the possibility for relationship and alliance building within the respected boundaries of US Native nations' sovereignty. 
Further, this project is inspired by the institution-building and intellectual projects of hemispheric Indigenous studies and comparative indigeneities (Castellanos et al. 2012; Mallón 2012; de la Cadena and Starn 2007). A Critical Latinx Indigeneities perspective is situated at a crossroads that further exposes complex intersectional nuances, intergroup oppression, and enduring multiple colonialities of power. It complicates the ways indigeneity has been taken up in the subfields of Latina/o studies. Chicana scholars have interrogated indigeneity in the Chicano and Mexican-American context. Saldaña-Portillo's seminal essay, "Who Is the Indian in Aztlán?" (2001), set the stage to interrogate the construction of indigeneity and mestizaje within the Chicano cultural projection. Other scholars such as Sheila Contreras in Bloodlines (2008) undertook an exploration of Chicana/o indigenism and its usage of a symbolic archive that "draws from preceding traditions of Mexican indigenism and European primitivism" (p. 6). Lourdes Alberto (2012) has examined the use of indigenismo in the Chicana feminist canon. Indigenismo is a mestizo intellectual and cultural movement in Latin America in which national elites imagined and constructed the unity of the nation by recognizing the grandeur of the Indigenous civilizations while denying the Indigenous present. Yet, in some realms of Chicana/o Studies, indigenismo has been made to stand in for indigeneity. The confusion seems rooted in the ways the Chicano Movement recycled Mexican state notions of indigenismo through an Aztec-centric celebration of the Indigenous past of the nation, which often serves to erase the present and future of the sixtythree other Indigenous pueblos of Mexico (Blackwell forthcoming). Indigenismo as a state ideology and intellectual project has gone hand in hand with mestizaje, which functions, not so much as a celebration of racial mixture, as has been heralded in a Chicana/o national imaginary, but more as a program of racial whitening (GuidottiHernández 2011). While Castellaños, Gutierrez and Aldama do important work exploring how mestizaje has been reclaimed by Chicana cultural workers, other scholars insist that it is ultimately a racial category that erases indigeneity via the guise of inclusion (Alberto forthcoming).

This special issue of Latino Studies calls for more than disaggregating and highlighting the complexity and nuances of Latinx populations and moves beyond recognition politics. Critical Latinx Indigeneities uses the experiences and epistemes of Indigenous Latinxs to push the boundaries of seemingly distinct disciplines to form an interdisciplinary analysis of indigeneity that is critical of mestizaje and racial whitening across national borders. By centering these experiences and epistemologies, we propose a shift in the field of Latina/o studies and Latinidad as a whole, to create room for the multilayered discourses and ideologies of local, national, and transnational social and cultural flows both in Latin America and in diaspora.

We draw from critical Indigenous studies to think about how the process of mobility and migration contributes to settler colonial projects of elimination. How do more newly arrived Indigenous groups relate to Indigenous peoples of the lands they now live and work in? How will the US-based forms of belonging conflict with Latin American state definitions and Indigenous community definitions? How is mobility, traditionally understood as a cause of cultural loss, producing new forms of Indigenous consciousness? Will this create new possibilities for solidarity, or 
conflict, or both? With these questions, we frame Latina/o studies and Critical Latinx Indigeneities within a comparative ethnic studies and hemispheric framework by exploring the challenges Indigenous Latinxs represent to various academic disciplines and to the structural nationalist conceptions of indigeneity and "nativeness" throughout the hemisphere.

Because of these questions, we keep the "Latina/o" in Critical Latinx Indigeneities as an effort to not automatically dismiss the possibility that Indigenous migrants can enact settler colonial logics, while also recognizing that Native studies consolidated and defined the forms of politics within which Indigenous (tribal) peoples in the North exist in relation to Indigenous nationhood and the settler state. Rather than assume a pan-indigeneity, many of the scholars in this special issue root their analysis in particular communities in order to consider the tensions that arise when Indigenous migrants are positioned as part of a settler colonial force that continues the dispossession and erasure of Northern Native people who struggle for their sovereignty. We use Latinx with an eye to how it has been historically, socially, economically and politically constructed and absorbed within a US racial landscape, but we also cannot ignore that one indigeneity does not supplant another. Thinking about layered, complex, multifocal, and multi-vocal Indigenous communities requires that we engage the fact that Latinidad, for better or worse, shapes part of the experience for Indigenous migrants from Latin America, especially upon entering the US. Given the prominence of globalization, we need to emphasize that race still matters even as we recognize that racialization may shift from one country to another and across transregions of Indigenous migrations. Critical Latinx Indigeneities is needed, in order to continue thinking about how power is distributed along ethnicity and race across contexts, even at this neoliberal, color-blind moment.

Critical Latinx Indigeneity is building a perspective, or standpoint, that draws from the personal stories, interpretive lenses, ways of knowing, and ways of being of Indigenous Latinxs from what is now the US or who have arrived via migration from Latin America where second and future generations of Indigenous migrants, especially youth, address their complex and multilayered realities. This analytic frame is needed because there has not been, until now, a collective effort to name and theorize the various expressions of these experiences, which tend to be outside of, but also within, dominant narratives such as Latinidad and often in tension with Hispanic, and Chicana/o. Critical Latinx Indigeneity fills a need to critically engage and critique enduring colonial logics and practices that operate from different localities of power as well as the physical, social, cultural, economic, and psychological violence that often targets Indigenous Latinx peoples, including forms of state and police violence, cultural appropriation, economic exploitation, gender violence, social exclusion, and psychological abuse. Critical Latinx Indigeneities unpacks the particularities of these Indigenous Latinx multilayered experiences that invite a more nuanced and profound knowledge and reflection on history and racial constructions and subordination across various national and international contexts, including those of sovereign tribal nations.

Critical Latinx Indigeneities makes room for the various forms of resistance, including activism, rage, healing, love, and communality that inform Latinx Indigenous experiences in the US and beyond. Critical Latinx Indigeneities exposes 
complex intersectional nuances, inter-group oppression, and enduring colonialist power dynamics within Whiteness, Blackness, Latinidad, and also within American Indian politics of identity. These larger narratives of experience such as Hispanic, Latino, Chicano, often attempt to disappear and assimilate. Critical Latinx Indigeneities challenges these erasures and carves out a unique space of its own. Critical Latinx Indigeneity calls all migrants and nonmigrants to acknowledge settler status on Indigenous lands and to respect the unique political relationship of US tribal sovereignty, while simultaneously re(integrating) race into the analysis of indigeneity beyond the politics of Indigenous recognition in relation to the tribal/settler state binary. Unlike the ways the categories of "Hispanic," "Mexican" or "Latino" usually obscure Indigenous roots, we are calling attention to the millions who are still connected to our genealogical, millennial, Indigenous histories and presents. Critical Latinx Indigeneities further shifts the conversation because it does not shy away from a more complex analysis of experience that requires a more engaged reading and analysis of history and the various structural systems that impact the experiences of Indigenous Latinx migrants and their future generations in the US (and Latin America through various return migrations, including that of US-born Indigenous Latinx children who are deported along with their undocumented parents).

\section{Remapping indigeneity, gender, migration and cultural production}

Building on the development of Critical Latinx Indigeneities, the contributors to this special issue of Latino Studies center Indigenous epistemologies in rethinking the Latina/o experience in terms of meanings of race, migration, and youth organizing. Each piece adds a different layer to engage the multiraciality of Latinidad and how, increasingly, identities are constructed through indigeneity. Further, each piece explores how Indigenous activism and epistemologies (re)frame the field and the Latina/o experience. María Josefina Saldaña-Portillo's essay, "Critical Latinx Indigeneities: A paradigm drift," asks "When Is an Indian Not an Indian?" She examines the construction of indigeneity within historic and contemporary US racial ideologies. Indigenous disappearance from any racial mixture, coupled with the portrayal of Indigenous bodies as wasted/wasteful were part of labor schema, she argues, that justified the enslavement of Africans and the annexation of Mexico. Bringing these logics into the debates about the recent wave of Central American refugees, specifically Garífuna mothers and children in New York, Saldaña-Portillo tracks how global capital in the guise of free trade conspired with the Honduran government to create a unique, if invisible, form of Indigenous detribalization and dispossession. She uses a Critical Latinx Indigeneities framework to also examine the prison industrial complex and settler colonialism in invigorating and fresh ways.

Maylei Blackwell, in "Geographies of Indigeneity," explores Zapotec and Mayan migration to Los Angeles to map new geographies of indigeneity. Focusing on Zapotec women's organizing, she points to the sacred geographies, new circuits of labor and organizing, and spatial projects of the large Oaxacan community within the city. Blackwell argues that these projects need to be considered in relation to multiple Latin American and US settler colonialities that are only legible through a Critical Latinx Indigeneities lens. She elaborates this framework to unpack the 
complexities of these socio-spacial and political relations, especially in regard to the relationship with and among the displaced Latin American Indigenous migrants and the Native peoples of LA.

Gloria E. Chacón, in her essay "Metamestizaje and the Narration of the Political Movements from the South," unpacks the fictionalized romances in Graciela Limón's Erased Faces, Ana Castillo's Sapogonia, and Demetria Martinez's Mother Tongue to discuss how the discursive mechanisms of indigenismo and what she theorizes as "metamestizaje" allow the authors to plot the social and political conflicts through fiction. Chacón theorizes metamestizaje as a racialized discourse that stems from the European encounter with Indigenous peoples, which writers use to restage tropes of mixing through romantic couplings. Her gendered analytics examine how the critical intersections and interventions of US Latinx literatures with a Mesoamerican Indigenous imaginary provoke necessary conversations and political projects in both interdisciplinary fields, thereby insisting that Latinx literary representations of indigeneity be responsive to Indigenous cultural productions.

Floridalma Boj Lopez, in her article "Mobile archives of Indigeneity," analyzes cultural production within La Comunidad Ixim, a Maya youth group in Los Angeles, California. Based on interviews with the organizers and participants, she provides a close reading of the children's book that the group has created in order to demonstrate how youth reflect the process of defining themselves as Maya in the narrative and stylistic choices of the book. Arguing against cultural loss and erasure, Boj Lopez highlights this children's book as a mobile archive of indigeneity that bends and blurs categories of Latinx and Maya in an effort to create bridges for other Mayas in the diaspora. Additionally, she examines how this archive has the potential to reconceptualize migration as part of an intergenerational experience of Indigenous dispossession, but not one that automatically equates a complete loss or rupture since groups like La Comunidad Ixim frequently create tools and strategies that can account for the complexity of indigeneity in the 21 st century.

In "Rewriting the Mexican Immigrant Narrative," M. Bianet Castellanos traces and maps out Yucatec Maya women's migration narratives and their relationship to dominant narratives of Mexican immigration. Through her analysis of the immigrant narrative structure and her researcher reflexivity, Castellanos reveals how Indigenous identity becomes obscured and then strategically resurfaces in Yucatec Maya women's immigration narratives. By tracing the tropes of liberation and flight, Castellanos also focuses on "gestures" toward Indigenous ways of knowing and being in Yucatec Maya women's lives that dispute settler colonial and colonial logics of erasure.

Our issue also includes three vivencias that more intimately examine the interplay of Latinidad and indigeneity. In the first, Luis Sánchez-López, a member of the Zapotec community in Los Angeles, California, draws on the insights of comunalidad to urge us to dismantle essentialist understandings of indigeneity by thinking of Zapotecs' sense of belonging as something that is forged through one's work on behalf of the pueblo. In the second, Lourdes Alberto examines how Indigenous Mexicans "come out" to call attention to Indigenous subjectivity and articulate difference within Latinidad. Alberto finds possibility in public declarations of indigeneity by Indigenous Latinxs as a way to destabilize essentialist 
notions of both Latina/o and Indigenous categories of identification and to critique global forms of colonial legacies. Finally, Luis Urrieta Jr. examines two personal reflections about complex Indigenous identity-making experiences, one in Mexico and one in the US, that highlight the separate, but intersecting, complicated, and contested ways indigeneity gets constructed in diaspora compared with the structured dictates of nationalist constructs of indigenismo in home countries.

Overall, the articles in this special issue will challenge the field of Latina/o studies with critical and generative explorations of the intersections, layers, and nuances of Latinxs' experiences by addressing a growing sector of the Latinx community that is often invisiblized, or relegated to a distant romanticized past. Each of these papers highlights the epistemological insight of Indigenous Latinx experiences and situates these experiences within and outside the larger sociopolitical and cultural landscapes of Latinidades.

Finally, we want to recognize that for many of us involved in this field-building project, these are not mere intellectual pursuits, but ones that build on the intimate relationships we have with these communities. It is our relationships-either as members of the Indigenous communities we write about or as outsiders who the communities have welcomed-that define our investments in writing and telling these stories. These narratives and critiques are often silenced, made invisible or dismissed in dominant narratives of Latinidad. We also want to add that our collaboration has grown out of a consistent commitment to intergenerational dialogue between activist and immigrant generations as well as between graduate students and faculty. From the initial conversations that gave way to a Critical Latinx Indigeneities Symposium, held at the University of Texas at Austin on March 26, 2015, ${ }^{5}$ to now, we have sought to remain conscious of the power dynamics that frame the student-professor relationship and honor the work that more advanced scholars have produced that laid the groundwork for our current conversations to take place while also creating space for graduate students to add a critical component and new voices in this field-building endeavor. As such, building this field extends beyond the analysis present in written text to the various forms of accountability and reciprocity that we have sought to have embedded in our work with each other.

\section{References}

Aikau, H.K. 2010. Indigeneity in the Diaspora: The Case of Native Hawaiians in Iosepa, Utah. American Quarterly 62: 477-500.

\footnotetext{
5 The Critical Latino Indigeneities Symposium, organized by Luis Urrieta, was held on March 26, 2015, and co-sponsored by the Mexico Center of the Lozano Long-Benson Institute of Latin American Studies, the Mexican-American and Latino Studies Department, the Native American and Indigenous Studies Program, the Department of Curriculum and Instruction, and the Graduate School at the University of Texas-Austin. A second "Critical Latino Indigeneities Symposium: An Interdisciplinary Symposium on the Latin American Indigenous Diaspora in the U.S." was organized by Lourdes Alberto at the University of Utah and co-sponsored by Ethnic Studies, Center for Latin American Studies, the Departments of English and History and the Office of Equity and Diversity.
} 
Alberto, L. 2012. Topographies of Indigenism: Mexico, Decolonial Indigenism, and the Chicana Transnational Subject in Ana Castillo's Mixquiahuala Letters. In Comparative Indignities Towards a Hemispheric Approach, ed. M. Bianet Castellanos, Lourdes Gutiérrez Nájera and Arturo J. Aldama, 38-52. Toronto: University of British Columbia Press.

Alberto, L. Forthcoming. Mexican American Indigeneities. New York: New York University Press.

Barillas-Chon, D. 2010. Oaxaqueño/a Students' (Un)welcoming High School Experiences. Journal of Latinos and Education 9 (4): 303-320. doi:10.1080/15348431.2010.491043.

Barker, J. 2011. Native Acts: Law, Recognition, and Cultural Authenticity. Durham: Duke University Press.

Bauerkemper, J., and H.K. Stark. 2012. The Trans/national Terrain of Anishinaabe Law and Diplomacy. Journal of Transnational American Studies 4 (1): 1-21.

Blackwell, M. 2010. Líderes Campesinas: Nepantla Strategies and Grassroots Organizing at the Intersection of Gender and Globalization. Aztlán: A Journal of Chicano Studies 35 (1): 13-48.

Blackwell, M. Forthcoming. Indigeneity. In Latino Keywords, ed. L. La Fountain-Stokes, N. Mirabal, and D. R. Vargas. New York: New York University Press.

Boj Lopez, F. 2015. Mobilizing Transgression: Red Pedagogy and Maya Migrant Positionalities. In Red Pedagogy: Native American Social and Political Thought, 10th Anniversary, deluxe ed, ed. S. Grande. Lanham: Rowman and Littlefield.

Byrd, J.A. 2011. The Transit of Empire: Indigenous Critiques of Colonialism. Minneapolis: University of Minnesota Press.

Castellanos, M.B., L.G. Nájera, and A.J. Aldama (eds.). 2012. Comparative Indignities: Towards a Hemispheric Approach. Tucson: University of Arizona Press.

Contreras, S. 2008. Blood Lines: Myth, Indigenism and Chicana/o Literature. Austin: University of Texas Press.

Coulthard, G.S. 2014. Red Skin, White Masks: Rejecting the Colonial Politics of Recognition. Minneapolis: University of Minnesota Press.

de la Cadena, M., and O. Starn. 2007. Indigenous Experiences Today. Oxford: Berg.

Fox, J. 2006. Reframing Mexican Migration as a Multi-Ethnic Process. Latino Studies 4 (1-2): 39-61.

Fox, J., and G. Rivera-Salgado (eds.). 2004. Indigenous Mexican Migrants in the United States. La Jolla: Center for U.S.-Mexican Studies, University of California San Diego.

Fujikane, C., and J.Y. Okamura. 2008. Asian Settler Colonialism: From Local Governance to the Habits of Everyday Life in Hawai'i. Honolulu: University of Hawai'i Press.

Grande, S. 2015. Red Pedagogy: Native American Social and Political Thought, 10th Anniversary, deluxe ed. Lanham, MD: Rowman and Littlefield.

Guidotti-Hernández, N. 2011. Unspeakable Violence: Remapping U.S. and Mexican National Imaginaries. Durham: Duke University Press.

Hernandez, D.M. 2015. Unaccompanied Child Migrants in "Crisis": New Surge or Case of Arrested Development? Harvard Journal of Hispanic Policy 27: 11.

Herrera, J. 2016. Racialized Illegality: The Regulation of Informal Labor and Space. Latino Studies 14 (3): 320 .

Huang, H., P. Deloria, L. Furlan, and J. Gamber. 2012. Charting Transnational Native American Studies. Journal of Transnational American Studies 4 (1): 1-15.

Jonas, S., and N. Rodríguez. 2015. Guatemala-U.S. Migration: Transforming Regions. Austin: University of Texas Press.

Kearney, M. 2000. Transnational Oaxacan Indigenous Identity: The Case of the Mixtecs and Zapotecs. Identities: Global Studies in Culture and Power 7 (2): 173-195.

Mallón, F.E. 2012. Decolonizing Native Histories: Collaboration, Knowledge, and Language in the Americas. Durham: Duke University Press.

Menjívar, C., and L. Abrego. 2012. Legal Violence in the Lives of Immigrants: How Immigration Enforcement Affects Families, Schools, and Workplaces. Washington, DC: Center for American Progress.

Moreton-Robinson, A. 2016. Critical Indigenous Studies: Engagements in First World Locations. Tucson: University of Arizona Press.

O'Brien, J.M. 2010. Firsting and Lasting: Writing Indians Out of Existence in New England. Minneapolis: University of Minnesota Press.

Reynolds, J.F. 2013. (Be)laboring Childhoods in Postville, Iowa. Anthropological Quarterly 86 (3): 851-889. doi:10.1353/anq.2013.0044. 
Rifkin, M. 2014. Settler Common Sense: Queerness and Everyday Colonialism in the American Renaissance. Minneapolis: University of Minnesota Press.

Saldaña-Portillo, M.J. 2001. Who's the Indian in Aztlan? Re-writing Mestizaje, Indianism, and Chicanismo from the Lacandon. In The latin American subaltern studies reader, ed. I. Rodriguez, 402-423. Durham: Duke University Press.

Simpson, A. 2014. Mohawk Interruptus: Political life across the Borders of Settler States. Durham: Duke University Press.

Simpson, A., and A. Smith. 2014. Theorizing Native Studies. Durham: Duke University Press.

Southwest Border Unaccompanied Alien Children Statistics FY 2016. U.S. Customs and Border Protection. http://www.cbp.gov/newsroom/stats/southwest-border-unaccompanied-children/fy-2016. Accessed February 9, 2016.

Stephen, L. 2007. Transborder Lives: Indigenous Oaxacans in Mexico, California, and Oregon. Durham: Duke University Press.

Urrieta Jr., L. 2016. Diasporic Community Smartness: Saberes (Knowings) Beyond Schooling and Borders. Race, Ethnicity and Education 19 (6): 1186-1199.

Velasco, L.O. 2005. Mixtec Transnational Identity. Tucson: University of Arizona Press.

Warrior, R. 2009. Native American Scholarship and the Transnational Turn. Cultural Studies Review 15 (2): 119-130.

Wolfe, P. 1999. Settler Colonialism and the Transformation of Anthropology: The Politics and Poetics of an Ethnographic Event. New York: Cassell.

Wolfe, P. 2006. Settler Colonialism and the Elimination of the Native. Journal of Genocide Research 8 (4): 387-409.

Associate Professor Maylei Blackwell is the author of the landmark Chicana Power!: Contested Histories of Feminism in the Chicano Movement (2011). Dr. Blackwell's publications have appeared in the U.S., Mexico and Beazil in journals such as Meridians, Signs, Aztlán, Journal of Latin American Studies, Desacatos, and Revista Estudos Feministas on research ranging from women's social meovements in the U.S. and Latin America, transnational activism, indigenous politics and migration. Her fortcoming book is entitled Scales of Resistance: Indigenous Autonomy in the Age of Neoliberalism with Duke University Press. She co-edits the digital story mapping project Mapping Indigenous Los Angeles (mila.ssc.ucla.edu).

Floridalma Boj Lopez completed her doctorate in American Studies and Ethnicity at the University of Southern California. Her research examines cultural production among the Maya diaspora with a particular emphasis on intergenerational imaginaries, gender, and the production of Indigenous migrant community in Los Angeles, California.

Luis Urrieta, Jr. is Associate Professor of Cultural Studies of Education at the University of Texas at Austin. He is the author of Working from Within: Chicana and Chicano Activist Educators in Whitestream Schools (2009). His research interests include Chicanx, Latinx, and Indigenous education; Indigenous migrations and diasporas, Indigenous knowledge systems and research methodologies. His forthcoming co-edited book is entitled The Cultural Construction of Identity: Meta-ethnpography and Theory with Oxford University Press. 